\title{
The Pennsylvanian conodont genus Gondolella Stauffer \& Plummer, 1932: reinterpretation of the original type specimens and concepts
}

\author{
GLEN K. MERRILL ${ }^{1} \&$ PETER H. VON BITTER ${ }^{2}$ \\ ${ }^{1}$ University of Houston - Downtown, Houston, TX 77002, USA (e-mail: merrillg@uhd.edu) \\ ${ }^{2}$ Royal Ontario Museum and University of Toronto, Toronto, Canada M5S 2C6
}

\begin{abstract}
In order to ensure stability of nomenclature among species of Gondolella, lectotypes are selected from among the cotypes (syntypes in modern usage) proposed by Stauffer \& Plummer (1932) for species that it is concluded were parts of the apparatuses of two species of that genus. It is recognized that many of their specimens actually represent growth stages of individual species, and many of the names used by Stauffer \& Plummer are placed in synonymy. Interpreted synonyms include not only gondolelliform $\mathrm{P}_{1}$ elements, but other parts of the apparatus, especially $\mathrm{P}_{2}$ elements assigned to Euprioniodina by Stauffer \& Plummer. Thus, Gondolella bella has synonyms as $\mathrm{P}_{1}$ elements: G. curvata, G. magna, G. minuta, probably $G$. sp. A, $\mathrm{S}_{1}$ element Euprioniodina coronata and $\mathrm{P}_{2}$ elements: E. exserta, E. eximia and E. intertexta. In a similar manner, the type species of the genus, Gondolella elegantula, has synonyms $G$. insolita, G. lanceolata ( $\mathrm{P}_{1}$ elements), and probably Euprioniodina sp. B ( $\mathrm{P}_{2}$ element?). J. Micropalaeontol. 26(1): 41-46, April 2007.
\end{abstract}

KEYWORDS: Gondolella, Pennsylvanian, conodonts, Stauffer \& Plummer, Texas

\section{INTRODUCTION, APPARATUSES AND ONTOGENY}

Stauffer \& Plummer based their 1932 concept of the genus Gondolella on gondola-shaped platform (pectiniform) elements from the Pennsylvanian of north-central Texas. Subsequent work (Rhodes, 1952; von Bitter, 1976; von Bitter \& Merrill, 1998) showed that these gondola-shaped platform elements were parts of a skeletal apparatus that included several other kinds of elements. Thus, element types of differing morphologies occurring in single samples may be biologically parts of the apparatus of Gondolella, rather than just being ecological associates as postulated by Merrill (1973). This is also the case with several of Stauffer \& Plummer's non-platform taxa; they are parts of and synonyms of species of Gondolella.

The designated type species of Gondolella is G. elegantula Stauffer \& Plummer, by original designation. It remains so in spite of the attempt by Clark \& Mosher (1966) to make that species a junior synonym of G. bella Stauffer \& Plummer, described in the same 1932 work. Clark \& Mosher (1966) used G. bella as the name for the synonymized species based, apparently, on page priority. This action has no status, because, even if one were to agree with their subjective synonymy - which the current paper does not - the original intent and the legally adequate designation by the original authors must prevail under Article 68.2 of the International Code of Zoological Nomenclature (ITZN, 1999).

That Clark \& Mosher (1966) attempted to synonymize Gondolella elegantula and G. bella is not surprising because they look quite similar, in spite of being of significantly different geological ages. The reason for this apparent similarity is that the cotypes and paratype of G. elegantula and the holotype of G. bella are all juvenile (small) specimens. Stauffer \& Plummer apparently used size as well as ornamentation as a specific criterion. Thus, a cotype of $G$. insolita (BEG 19156) has a reconstructed length of $0.9 \mathrm{~mm}$, in contrast with a cotype of G. elegantula (BEG 19154) that is $0.2 \mathrm{~mm}$ shorter. Similarly, the incomplete cotype of $G$. magna (BEG 19158) has an extrapolated length of over $1.3 \mathrm{~mm}$ whereas the complete holotype of G. bella (BEG 19152) from the same sample is only half as long $(0.7 \mathrm{~mm})$. This practice of describing and naming juvenile specimens makes it difficult to compare species of different geological ages because juveniles from different parts of the phylogeny bear a strong resemblance to one another. Fortunately, the authors have been able to recollect the locus typicus and stratum typicum for each of Stauffer \& Plummer's gondolellid species, permitting their juvenile types to be placed in ontogenetic context. This study can, therefore, compare their types and recognize synonyms among them.

\section{MATERIALS AND METHODS, RE-EVALUATION OF STAUFFER \& PLUMMER'S TYPES AND SELECTION OF LECTOTYPES}

For the sake of taxonomic stability it is deemed necessary to select lectotypes from among Stauffer \& Plummers' cotypes (Table 1).

\section{Geographical and stratigraphical constraints}

Stauffer \& Plummer's locality register credits others for collecting samples used in their study. Helen Jean Plummer's husband, F. B. Plummer, who was later State Geologist of Texas, apparently collected the bulk of these. Probably neither H. J. Plummer nor C. R. Stauffer visited any of the localities from which their collections were derived. Such disengagement of source and students opened the door for miscommunication of geographical and stratigraphical information unrelated to the specimens themselves. So it was with Stauffer \& Plummer's sample information.

Although Stauffer \& Plummer (1932) described conodonts from several other localities, only two of their localities yielded specimens of Gondolella. The geologically older of these was an upper Desmoinesian locality in Mineral Wells, Palo Pinto County, Texas, the well-known East Mountain locality. The 


\begin{tabular}{|c|c|c|c|c|c|}
\hline $\begin{array}{l}\text { Stauffer \& Plummer's } \\
\text { taxon }\end{array}$ & $\begin{array}{c}\text { Stauffer \& } \\
\text { Plummer's figure }\end{array}$ & $\begin{array}{c}\text { BEG } \\
\text { number }{ }^{\mathrm{a}}\end{array}$ & $\begin{array}{l}\text { Stratigraphic } \\
\text { position }\end{array}$ & $\begin{array}{c}\text { Stauffer \& } \\
\text { Plummer's locality }\end{array}$ & Comments \\
\hline Gondolella curvata & pl. 3 , figs 13,14 & 19153 & East Mountain Shale & Mineral Wells & Slightly more complete specimen \\
\hline Gondolella elegantula & pl. 3 , fig. 8 & 19154 & Posideon Shale & Wiles & Slightly more mature specimen \\
\hline Gondolella insolita & pl. 3, fig. 15 & 19156 & Posideon Shale & Wiles & \\
\hline Gondolella lanceolata & pl. 3, fig. 16 & 20945 & Posideon Shale & Wiles & \\
\hline
\end{tabular}

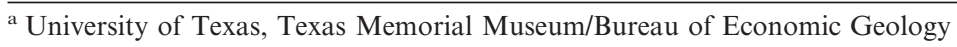

Table 1. Current selections/designations of lectotypes between the cotypes (syntypes) of Stauffer \& Plummer (1932).

other locality was more cryptically described, but was a lower Missourian locality near Wiles, Stephens County, Texas. The latter locality became the locus typicus for their type species, Gondolella elegantula.

Despite the fact that the East Mountain locality is well known and can be located precisely (14SNM839303 or $32^{\circ} 47^{\prime} 58^{\prime \prime} \mathrm{N}$ $\left.98^{\circ} 11^{\prime} 02^{\prime \prime} \mathrm{W}\right)$, even here there was sample confusion. According to Stauffer \& Plummer's locality register, they had samples from two intervals here, one a 'soft gray shale ... about ten feet above the base' of the section, and the other a 'dark' shale near the top of the section 'about ten feet below the Lake Pinto sandstone' (Stauffer \& Plummer, 1932: 22-23). If this was correct, their samples were separated by more than 110 feet $(33.5 \mathrm{~m})$ of strata. Immediately apparent from an examination of the locality is that there is no black shale 'ten feet below the Lake Pinto sandstone'. The only black shale in the section occurs $10 \mathrm{~m}$ above the base of the section. Furthermore, continuous sampling from the base of the Lake Pinto Sandstone downward to the base of the section revealed only a single bed that could have yielded the faunas reported by Stauffer \& Plummer as having come from two levels - the black shale $10 \mathrm{~m}$ above the base of the section. It is likely that what they listed as samples 181-T9-A and 181-T-9-B were, in fact, both derived from this shale $10 \mathrm{~m}$ above the base of the section and not one, but both, of their listed sample intervals were incorrect. This singularity of sampling has had an impact on gondolellid taxonomy and subsequent attempts to build a phylogenetic tree and biostratigraphical framework based on a distinction between somewhat less advanced forms from their 'lower' sample and somewhat more advanced ones from their 'upper' one (referred to as Gondolella bella and G. magna, respectively by Merrill, 1975). Realization that they were members of a continuous population necessitates taxonomic and phylogenetic revisions.

Stauffer \& Plummer's other locality near Wiles has been relocated and, together with the East Mountain locality, was discussed and described by Merrill et al. (1987) and Merrill \& Grayson (1989). Briefly, it can be located precisely at $14 \mathrm{SLN} 38919989$ or $32^{\circ} 32^{\prime} 14^{\prime \prime} \mathrm{N} 98^{\circ} 35^{\prime} 08^{\prime \prime} \mathrm{W}$ in a lightcoloured, shelly shale directly above the Wiles Limestone.

All elements from Stauffer \& Plummer (1932) are purposely re-illustrated in the same orientation as they were in their paper; the upper surfaces of $\mathrm{P}_{1}$ elements, photographed using electron microscopy, have thus been re-illustrated with the posterior part of the element toward the top of the page, and the anterior part toward the bottom. This practice achieves consistency between Stauffer \& Plummer's (1932) publication and the current paper one of the aims; it is also consistent with the orientation shown for Gondolella and other $\mathrm{P}_{1}$ elements in Hass (1962) and Lindström (1964, fig. 55c) as well as specifically for Gondolella $\mathrm{P}_{1}$ elements illustrated by Klapper et al. (1981, figs $100.1 \mathrm{~b}$, 100.1c) and von Bitter \& Merrill (1998, fig. 3). M. A. Purnell (pers. comm., 2005) has pointed out that this orientation coincidently 'accords with in vivo orientation of $\mathrm{P}$ elements' within conodonts.

\section{SYSTEMATIC DESCRIPTIONS}

\section{General note}

The following descriptions and synonymies are based exclusively on materials from the Stauffer \& Plummer (1932) study and taxa subsequently described by others are not treated. Some parts of the synonymies were suggested by Merrill et al. (1987). Based upon ontogenetic analyses and apparatus reconstructions, several of Stauffer \& Plummer's taxa are placed in synonymy. Indeed, it is the authors' interpretation that only a single species of Gondolella was present at each of their two collecting sites and the other described species are either ontogenetic stages or anatomical associates. The species given alphabetical and page priority at each locality ( $G$. bella and $G$. elegantula) are thus chosen as name bearers, the latter unavoidably so because it is the type species by original designation. Element kinds are designated according to the system proposed by Purnell et al. (2000), but are orientated according to more conventional usage to facilitate comparison with the literature, including Stauffer \& Plummer's original work.

Stauffer \& Plummer's gondolellid material is re-illustrated in three different ways. Initially their drawings are reproduced (Plate 1$)$ at their original magnifications $(\times 40)$, arranged, where possible, in order of size and ontogenetic growth (e.g. illustrations 3A, 4A, 5A, etc.). Secondly, SEM micrographs of gondolellid $\mathrm{P}_{1}, \mathrm{P}_{2}$ and $\mathrm{S}$ elements are provided (Plate 1 ) at constant magnifications $(\times 60)$ in plan view, so that relative, true sizes may be compared. Finally, oblique views of $\mathrm{P}_{1}$ elements are provided at $\times 50$, so that morphological details may be seen more readily.

The specimen numbers have been listed in the manner in which the slides are labelled, with numbers carrying the prefix BEG for the Bureau of Economic Geology. Because the 
specimens are currently housed in the Texas Memorial Museum, a fuller prefix should read TMM/BEG, but the original has been retained for brevity.

Superfamily Gondoleloidea Lindström, 1970 Family Gondolellidae Lindström, 1970

Genus Gondolella Stauffer \& Plummer, 1932

Gondolella bella Stauffer \& Plummer, 1932

(P1. 1, figs 1A-12B)

v*1932 Gondolella bella Stauffer \& Plummer: 42, pl. 3, figs 3, 4 ( $\mathrm{P}_{1}$ element).

v 1932 Gondolella curvata Stauffer \& Plummer: 42, pl. 3, figs 13, 14, 17 ( $\mathrm{P}_{1}$ element).

v 1932 Gondolella magna Stauffer \& Plummer: 43, 44, pl. 3, figs

6, 7, 10, 11 ( $\mathrm{P}_{1}$ element).

v•1932 Gondolella minuta Stauffer \& Plummer: 44, pl. 3, figs 1, 2 ( $\mathrm{P}_{1}$ element).

?1932 Gondolella sp. A Stauffer \& Plummer: 44, pl. 3, figs 18, 19 ( $\mathrm{P}_{1}$ element).

v 1932 Euprioniodina coronata Stauffer \& Plummer: 30, 31, pl. 2, figs 7-9 ( $\mathrm{S}_{1}$ element).

v 1932 Euprioniodina exserta Stauffer \& Plummer: 31, pl. 2, fig. 22 ( $\mathrm{P}_{2}$ element).

v 1932 Euprioniodina eximia Stauffer \& Plummer: 31, pl. 2, fig. $36\left(\mathrm{P}_{2}\right.$ element $)$.

v 1932 Euprioniodina intertexta Stauffer \& Plummer: 32, pl. 2, fig. 35 ( $\mathrm{P}_{2}$ element).

Type species. Gondolella elegantula Stauffer \& Plummer, 1932, by original designation.

Diagnosis. A species of Gondolella in which the adult $\mathrm{P}_{1}$ elements are ornamented primarily by transverse ridges, some of which may cross the carinal row and many of which bifurcate laterally, producing 'facets' along the margins of the platform.

Locality. All illustrated and synonymized specimens are from a single locality (and by the authors' interpretation a single stratigraphic interval), the Mineral Wells Formation (now East Mountain Shale) in Mineral Wells, Palo Pinto Co., Texas, USA.

Description. ( $\mathrm{P}_{1}$ elements) Juvenile specimens (Pl. 1, figs 2, 3) are elongate with sharply pointed anterior and posterior termini, the former lacking any significant free blade and the latter consisting of the terminal denticle of the carinal row that is swept upward and posteriorly as the posterior terminus of the platform. Denticles of the carinal row are compressed laterally, sharply pointed, and more or less discrete. Oral surface of the platform is mostly plain with the lateral edges slightly upturned. A few small, discrete nodes may be present on the oral surface of the platform along the lateral margins, more commonly posteriorly (Pl. 1, figs 2, 3). During ontogeny the platform lengthens anteriorly and widens, the lateral nodes increase in number and become a continuous row of nodes that coalesce anteroposteriorly forming lateral ridges with slight scallops between nodes. The lateral nodes also extend medially as low ridges. With increasing maturity the lateral margins may become entirely scalloped or faceted by antero-posteriorly fused nodes. Cross-ridges developed from medial extension of the lateral nodes may form ridges that cross the carinal nodes and thus may extend from one platform margin to the other. Carinal nodes may become partially fused antero-posteriorly and connected with one another by a ridge or 'web' (Pl. 1, fig. 6). Overall platform shape in adult specimens is blunt or squared posteriorly and tapering gradually to a sharp anterior terminus without a significant free blade.

Remarks. The several 'species' of gondolellid $\mathrm{P}_{1}$ elements described by Stauffer \& Plummer, when arranged by size, make a convincing ontogenetic, or growth, series. Stauffer \& Plummer described several additional 'species', species that are interpreted to have been other elements within the apparatus of this species. These are figured ( $\mathrm{Pl}$. 1, figs 8-12), but not described, and it is concluded that they do not differ significantly from the homologous elements in the apparatuses of other species of Gondolella, such as G. pohli as described fully by von Bitter \& Merrill (1998). Gondolella sp. A of Stauffer \& Plummer (1932 pl. 3, figs 18, 19) is probably also a synonym; however, the specimen is missing and the assignment cannot be confirmed.

\section{Gondolella elegantula Stauffer \& Plummer, 1932}

(P1. 1, figs 13A-19C)

v*1932 Gondolella elegantula Stauffer \& Plummer: 42, 43, pl. 3, figs 5, 8, 9 ( $\mathrm{P}_{1}$ element).

v 1932 Gondolella insolita Stauffer \& Plummer: 43, pl. 3, figs 15, $22\left(\mathrm{P}_{1}\right.$ element $)$.

v 1932 Gondolella lanceolata Stauffer \& Plummer: 43, pl. 3, figs 12, 16 ( $\mathrm{P}_{1}$ element $)$.

?1932 Euprioniodina sp. B Stauffer \& Plummer: 32, pl. 2, fig. 34 ( $\mathrm{P}_{2}$ element?).

Diagnosis. A species of Gondolella in which the adult $\mathrm{P}_{1}$ elements are ornamented primarily by marginal ridges with lateral 'facets' that are the remnants of ancestral transverse ridges; some evidence of these ridges is present on ontogenetically less mature specimens.

Locality. All illustrated and synonymized specimens are from a single locality, the Graford Formation (now Posideon Shale), near Wiles townsite, Stephens Co., Texas, USA.

Description. ( $\mathrm{P}_{1}$ elements) Juvenile elements are elongate with sharply pointed anterior and posterior termini, the former with some small amount of free blade, the latter consisting of the terminal denticle swept upward and posteriorly and more or less a continuation of the entire posterior part of the platform. Denticles of the carinal row are compressed laterally, sharply pointed and more or less discrete. Oral surface of platform is mostly plain with lateral edges that are slightly upturned. A few small, discrete nodes may be present along one or both margins of the platform. These are more prominent posteriorly. During ontogeny the platform lengthens anteriorly, possibly retaining a short free blade. The platform also widens and develops ornamentation that consists of a row of nodes along each lateral margin of the platform. Each node shows a strong connection 


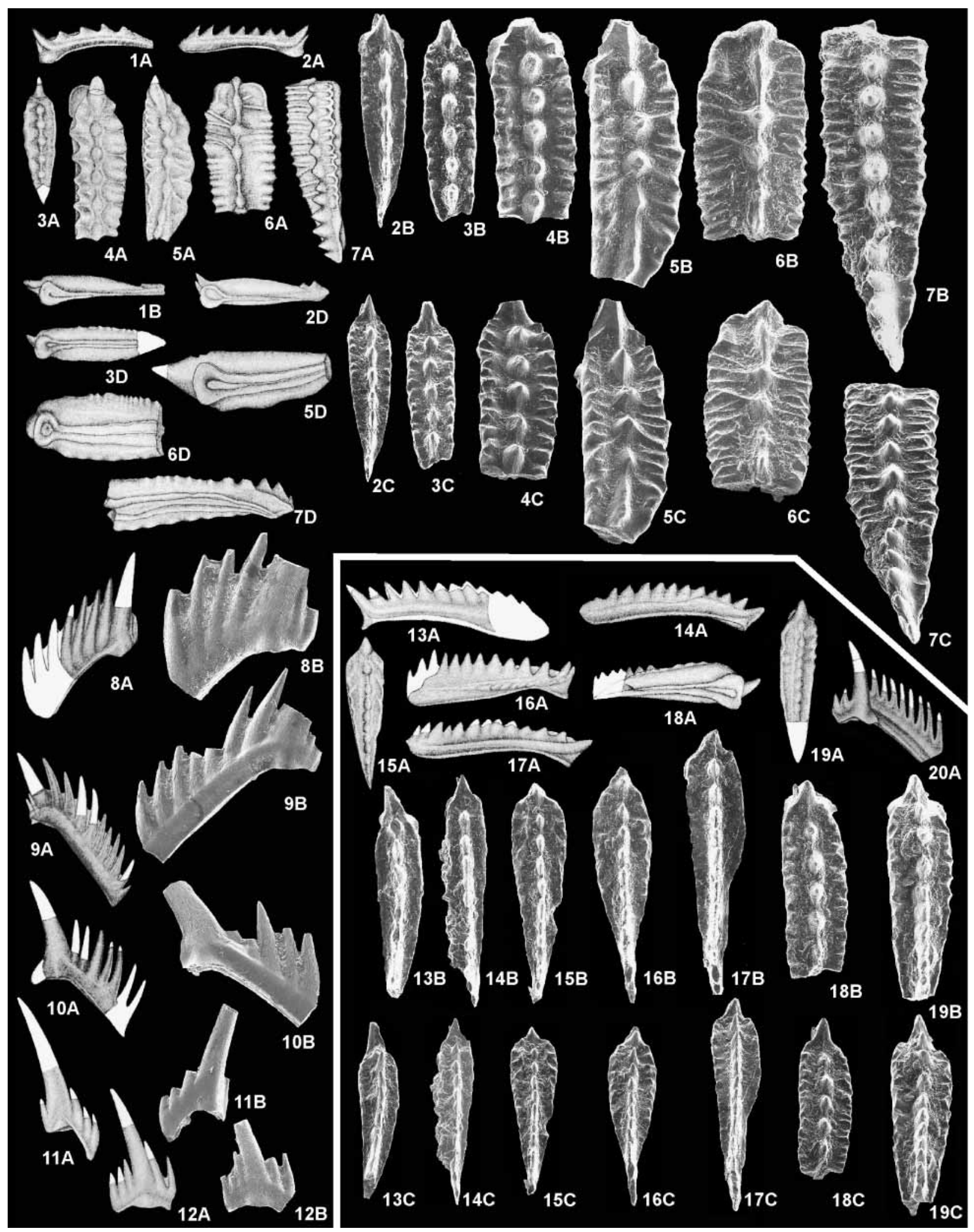


with adjacent nodes, producing numerous scallops, but little tendency to develop into lateral ridges.

Remarks. The most mature specimen of this species illustrated by Stauffer \& Plummer is their cotype of Gondolella insolita, which has been selected here as lectotype. That specimen is only submature, so that no fully adult specimen of the species is available from their collection; hence re-description of the type species of the genus must await description of available topotype material. Nevertheless, some differences are evident in the lack of prominent transverse ridges in Gondolella elegantula as opposed to those in G. bella. Stauffer \& Plummer's (1932) figured specimen of Euprioniodina sp. B appears to be the $\mathrm{P}_{2}$ element of a gondolellid apparatus and hence a probable junior synonym of $G$. elegantula, but the specimen is missing and identification cannot be confirmed.

\section{CONCLUSIONS}

Stauffer \& Plummer (1932) described a series of relatively different-looking platform elements as species of their new genus Gondolella. In conjunction with topotype material recovered by the authors, a re-study of their type specimens demonstrates that their collections came from only two horizons from different localities and that their several species at each of these are actually parts of a pair of continuous ontogenetic series. In other words, each of their localities actually yielded a single species of the genus and the necessary steps have been taken to place their several species in synonymy. Because such synonymy is subjective - and subject to future revision and modification by later workers - an important step toward taxonomic stability has also been taken by selecting lectotypes among Stauffer \& Plummer's cotypes. Finally, it should be noted that Stauffer \& Plummer (1932) also described several 'species' under the generic name Euprioniodina, 'species' that are actually elements other than the $\mathrm{P}_{1}$ elements of the apparatuses of species of Gondolella. By also listing these as junior synonyms of co-occurring gondolellid species, an attempt has been made to avoid the possibility that they might be considered senior synonyms at some future date. It is noted that Stauffer \& Plummer described gondolellid $\mathrm{P}_{2}$ (and other) elements under Euprioniodina, but described somewhat similar $\mathrm{P}_{2}$ elements of the Idiognathodus-Streptognathodus plexus under the generic name Bryantodus, as well as some other probable elements of that apparatus under such names as
Hindeodella. These specific names are also available and in competition and some could be resurrected as senior synonyms in the future.

\section{ACKNOWLEDGEMENTS}

The authors would first like to thank Dr Ann Molineux of the Texas Memorial Museum, The University of Texas at Austin for arranging the loan of these specimens for study and for permission to coat them for SEM illustration. Generally, arranging such a loan is not a complicated procedure, but in this case it was, and she made a great effort on the authors' behalf for which they are most grateful. In addition, Ms Kathy David, Royal Ontario Museum, Palaeobiology Section, Department of Natural History, carried out the scanning electron microscopy and digitally assembled Plate 1.

\section{Manuscript received 20 April 2005 Manuscript accepted 6 July 2006}

\section{REFERENCES}

Clark, D.L. \& Mosher, L.C. 1966. Stratigraphic, geographic and evolutionary development of the conodont genus Gondolella. Journal of Paleontology, 40: 376-394.

Hass, W.H. 1962. Treatise on Invertebrate Paleontology, part W. Geological Society of America and University of Kansas: 3-69.

International Trust for Zoological Nomenclature 1999. International Code of Zoological Nomenclature. ITZN, London, 306pp.

Klapper, G., Austin, R.L. \& Rhodes, F.H.T. 1981. In: Clark, D.L., Sweet, W.C., Bergström, S.M., et al. (Eds), Conodonta Treatise on Invertebrate Paleontology, Part $W$. Supplement 2. Geological Society of America and University of Kansas Press, 150-152.

Lindström, M. 1964. Conodonts. Elsevier, Amsterdam, 196pp.

Lindström, M. 1970. Supergeneric taxonomy of the conodonts. Lethaia, 3: $427-445$

Merrill, G.K. 1973. Pennsylvanian conodont paleoecology. Geological Society of America Special Paper, 141: 239-274.

Merrill, G.K. 1975. Pennsylvanian conodont biostratigraphy and paleoecology of northwestern Illinois. Geological Society of America Microform Publication, 3: 1-130.

Merrill, G.K. \& Grayson, R.C. Jr 1989. Conodont paleoecology in the type East Mountain Shale, North-central Texas. In: Boardman, D.R. II, Barrick, J.E., Cocke, J. \& Nestell, M.K. (Eds), Middle and Late Pennsylvanian chronostratigraphic boundaries in North-central Texas: glacial-eustatic events, biostratigraphy, and paleoecology. Texas Tech University Studies in Geology, 2: 234-249.

Merrill, G.K., Grayson, R.C. Jr \& Mosley, J.L. 1987. Restudy of the localities and conodont faunas of Stauffer and Plummer, 1932. In: Grayson, R.C. Jr, Merrill, G.K. \& Miller, J.F. (Eds), Early and late

Explanation of Plate 1.

figs 1-12. Gondolella bella from East Mountain Shale, Mineral Wells, Palo Pinto Co., Texas, USA. The illustrations to the left are the line drawings of Stauffer \& Plummer at their original publication scale of $\times 40$, those to the right designated with a 'B' suffix are vertical (oral) views at a constant $\times 60$, those designated with a 'C' suffix are oblique views at a constant $\times 50$ : 1, lateral and aboral views of $G$. sp. A, specimen lost; 2, lateral, oral, oblique and aboral views of the holotype of G. bella, BEG 19152; 3, oral, oral, oblique and aboral views of the holotype of G. minuta, BEG 19159; 4, oral, oral and oblique views of a cotype of G. curvata, BEG 20948; 5, oral, oral, oblique and aboral views of a cotype (now lectotype) of $G$. curvata, BEG 19153; 6, oral, oral, oblique and aboral views of a cotype (now lectotype) of G. magna, BEG 20944; 7, oral, oral, oblique and aboral views of a cotype of G. magna, BEG 19158; specimens illustrated in figs 8-12 are lateral views of non- $\mathrm{P}_{1}$ elements of G. bella - 8, holotype of Euprioniodina intertexta, BEG 19121 ( $\mathrm{P}_{2}$ element); 9, holotype of E. eximia, BEG 19118 ( $\mathrm{P}_{2}$ element); 10, holotype of E. exerta, BEG 19119 ( $\mathrm{P}_{2}$ element); 11, cotype (now lectotype) of $E$. coronata, BEG 20932 (S element=Sb, element in von Bitter \& Merrill, 1998); 12, cotype of E. coronata, BEG 19117 (S element=Sc element in von Bitter \& Merrill, 1998). figs 13-19. Gondolella elegantula from Posideon Shale, Wiles town site, Stephens Co., Texas, USA. Those above and with an 'A' suffix are the line drawings of Stauffer $\&$ Plummer at their original scale of $\times 40$, those with a 'B' suffix are vertical oral views at a constant $\times 60$, those with a ' $C$ ' suffix are oblique views at a constant $\times 50$ : 13, lateral, oral and oblique views, paratype of $G$. elegantula, BEG 19155; 14, lateral, oral and oblique views, cotype (now lectotype) of G. elegantula, BEG 19154; 15, oral, oral and oblique views, cotype (now lectotype) of G. lanceolata, BEG 20945; 16, lateral, oral and oblique views, cotype of G. lanceolata, BEG 19157; 17, lateral, oral and oblique views, cotype of G. elegantula, BEG 20946; 18, aboral, oral and oblique views, cotype of G. insolita, BEG 20947; 19, oral, oral and oblique views, cotype (now lectotype) of $G$. insolita, BEG 19156; 20, lateral view of Euprioniodina sp. B (probable $\mathrm{P}_{2}$ element, specimen lost. 
Paleozoic conodont faunas of the Llano Uplift region, central Texas biostratigraphy, systemic boundary relationships, and stratigraphic importance. South-central Section, Geological Society of America Guidebook: 23-45, 126-129.

Purnell, M.A., Donoghue, P.C.J. \& Aldridge, R.J. 2000. Orientation and anatomical notation in conodonts. Journal of Paleontology, $\mathbf{7 4}$ 113-122.

Rhodes, F.H.T. 1952. A classification of Pennsylvanian conodont assemblages. Journal of Paleontology, 26: 886-901.

Stauffer, C.R. \& Plummer, H.J. 1932. Texas Pennsylvanian conodonts and their stratigraphic relations. University of Texas Bulletin, 3201: $13-50$. von Bitter, P.H. 1976. The apparatus of Gondolella sublanceolata Gunnell (Conodontophorida, Upper Pennsylvanian) and its relationship to Illinella typica Rhodes. Royal Ontario Museum Life Science Contribution, 109: 1-44.

von Bitter, P.H. \& Merrill, G.K. 1998. Apparatus composition and structure of the Pennsylvanian conodont genus Gondolella based on assemblages from the Desmoinesian of northwestern Illinois, U.S.A. Journal of Paleontology, 72: 112-132. 